\title{
Effect of Feeding Graded Dietary Levels of Yeast Cell Extracted Nucleotides (YEN) at Different Age Intervals on Gut (Intestinal) Microbial Load of Commercial Broilers
}

\author{
H.C. Indresh*, Jayanaik, H.D. Narayanaswamy, M.C. Shivakumar, \\ T. Munegowda and B.C. Umashankar
}

\author{
Department of Poultry Science, Veterinary College, KVAFSU, Hebbal, Bangalore, India
}

*Corresponding author

\begin{tabular}{|c|c|}
\hline & A BSTRACT \\
\hline & \multirow{5}{*}{$\begin{array}{l}\text { An experiment was conducted to evaluate the effects of feeding graded levels of Yeast cell } \\
\text { extracted nucleotide (YEN) at different age intervals on Gut (Intestinal) microbial load of } \\
\text { commercial broilers. In a completely randomized design, } 300 \text { day-old straight run } \\
\text { commercial broiler chicks were assigned to ten treatments with each treatments consisting } \\
\text { of three replicates with ten chicks in each. Basal diet (control) } \mathrm{T}_{1} \text { was prepared without } \\
\text { supplementation of yeast extracted nucleotides for day } 1 \text { to } 42 \text { days of experimental } \\
\text { period. The birds in treatment groups } \mathrm{T}_{2}, \mathrm{~T}_{3} \text { and } \mathrm{T}_{4} \text { were fed with control diet } \\
\text { supplemented with } 1,2 \text { and } 3 \text { per cent yeast extracted nucleotides, respectively from day } 1 \\
\text { to } 14 \text { days and rest of the day upto } 42 \text { days control diet was fed. The birds in treatment } \\
\text { groups } \mathrm{T}_{5}, \mathrm{~T}_{6} \text { and } \mathrm{T}_{7} \text { were fed with control diet supplemented with } 1,2 \text { and } 3 \text { per cent } \\
\text { yeast extracted nucleotides, respectively from day } 1 \text { to } 28 \text { days and rest of the day upto } 42 \\
\text { days control diet was fed. The birds in treatment groups } \mathrm{T}_{8}, \mathrm{~T}_{9} \text { and } \mathrm{T}_{10} \text { were fed with } \\
\text { control diet supplemented with } 1,2 \text { and } 3 \text { per cent yeast extracted nucleotides, respectively } \\
\text { from day } 1 \text { to } 42 \text { days. The results of feeding YEN on gut microflora evident that feeding } \\
\text { of YEN at } 2 \text { and } 3 \text { per cent in birds from } 14 \text { days till } 42 \text { days resulted in significant } \\
\text { (P } \leq 0.05 \text { ) decrease in pathogenic } E \text {. coli and increase in beneficial Lactobacillus. However, } \\
\text { feeding YEN at } 2 \text { and } 3 \text { per cent up to } 28 \text { days was superior compared to } 14 \text { days and no } \\
\text { difference could be observed between } 28 \text { and } 42 \text { days feeding of YEN. Hence, it is } \\
\text { advocated that feeding YEN at } 2 \text { or } 3 \text { per cent up to } 28 \text { days would have better effect on } \\
\text { gut microflora in broilers. }\end{array}$} \\
\hline & \\
\hline Article II & \\
\hline & \\
\hline & \\
\hline
\end{tabular}

\section{Introduction}

Over the past few decades, antibiotic growthpromoters (AGPs) have been used in poultry feed to prevent bacterial infections, reduce mortality rate, and improve growth performance and production. However, inappropriate and excessive use of AGPs in animal feeds has led to antibiotic resistance development which is one of the major public health concerns (Cogliani et al., 2010).

Yeast-derived products including $31,3-1,6-$ glucan, mannan polysaccharides and nucleotides have been considered as one of the potential alternative supplements because of 
their growth promoting effects, immune modulatory and gut health maintaining properties (Brummer et al., 2010). It has been demonstrated that cell wall polysaccharides derived from the yeast such as Saccharomyces cerevisiae could cause significant improvement in growth performance by facilitating gut development and providing competitive binding sites for pathogenic bacteria (Muthusamy et al., 2011).

Nucleotides can be synthesized endogenously and are not considered as essential nutrients. However, the intestinal epithelium and lymphocytes of the gastrointestinal tract have rapid cell turnover and are unable to produce all the necessary nucleotides de novo to satisfy their own requirements (Li et al., 2005). Therefore, intestinal development is highly dependent on the presence of dietary nucleotides. Dietary nucleotides have an essential role in the development and proliferation of tissues and cells with a rapid cell turnover such as the intestine and lymphocytes where de novo synthesis of nucleotides cannot meet their demand in such rapidly proliferating tissues. The results of animal studies have shown that nucleotides can increase the development of the villi, intestinal wall thickness, protein content in the gastrointestinal tract and also improves gut microbial load (Mateo and Stein, 2004). Considering the role of nucleotides in the development of cells with rapid turnover (i.e., epithelial cells and lymphocytes) dietary nucleotides can probably modulate the gut microbial load of broiler chickens.

Based on the above observations, it was hypothesized that yeast cell derived nucleotide could become a significant source of yeast components that can probably stimulate the gut development and providing competitive binding sites for pathogenic bacteria. Hence, the present study has been carried out to study the effect of feeding graded levels of yeast cell extracted nucleotides on intestinal microbial load in broilers.

\section{Materials and Methods}

In a completely randomized design, 300 dayold straight run commercial broiler chicks were assigned to ten treatments with each treatments consisting of three replicates with ten chicks in each. Basal diet (control) $\mathrm{T}_{1}$ was prepared using corn and soya-bean meal as per the BIS (2007) standards (as per commercial requirement) without supplementation of yeast extracted nucleotides for day 1 to 42 days of experimental period. The birds in treatment groups $T_{2}, T_{3}$ and $T_{4}$ were fed with basal diet (control) supplemented with 1, 2 and 3 per cent yeast extracted nucleotides, respectively from day 1 to 14 days and rest of the day upto 42 days basal diet (control) was fed. The birds in treatment groups $\mathrm{T}_{5}, \mathrm{~T}_{6}$ and $\mathrm{T}_{7}$ were fed with basal diet (control) supplemented with 1 , 2 and 3 per cent yeast extracted nucleotides, respectively from day 1 to 28 days and rest of the day upto 42 days basal diet (control) was fed. The birds in treatment groups $\mathrm{T}_{8}, \mathrm{~T}_{9}$ and $\mathrm{T}_{10}$ were fed with basal diet (control) supplemented with 1, 2 and 3 per cent yeast extracted nucleotides, respectively from day 1 to 42 days (Table 1). Chemical composition of the yeast extracted nucleotides is provided in Table 3. All the birds were vaccinated against New castle disease and Infectious Bursal disease as per the schedule. Feed and water was provided ad libitum. Birds were reared on under standard managemental practices.

Microbiological parameters were assessed in terms of the Lactobacillus count and E. coli count. On 14th, 28th and 42nd day of experiment, two birds from each replicate in $\mathrm{T}_{1}$ to $\mathrm{T}_{4}, \mathrm{~T}_{1}$ to $\mathrm{T}_{7}$ and $\mathrm{T}_{1}$ to $\mathrm{T}_{10}$ treatment groups respectively were slaughtered. Intestinal content from duodenum, ileum and caeco colic were taken aseptically for microbial count. Samples were subjected for 
enumeration of bacteria as per spread plate method (Postgate, 1969). Specific media such as MacCankey agar was used for E. coli count, whereas Lactobacillus was assessed on Brain heart infusion agar by pour plate method (Mackie and Mccartey, 1996). Tenfold serial dilution of intestinal contents was used to assess the bacterial count. The bacterial counts were expressed as $\log _{10}$ colony forming units/ $\mathrm{gm}$ of the sample from intestinal content (Weir, 1990).

\section{Results and Discussion}

The results of the effect of feeding graded levels of yeast cell extracted nucleotides (YEN) on gut (intestinal) microbial $\operatorname{load}\left(\log _{10}\right.$ CFU/g) during $14^{\text {th }}, 28^{\text {th }}$ and $42^{\text {nd }}$ day in commercial broiler are presented in Table 2, 3 and 4 , respectively. At the end of $14^{\text {th }}$ day, the intestinal E. coli counts $\left(\log _{10} \mathrm{CFU} / \mathrm{g}\right)$ in group T1, T2, T3 and T4 were $7.14 \pm 0.025$, $7.16 \pm 0.008,6.80 \pm 0.037$ and $6.77 \pm 0.035$, respectively. A significant $(\mathrm{P} \leq 0.05)$ difference was observed in the intestinal $E$. coli counts among the treatments. ANOVA revealed a significant $(\mathrm{P} \leq 0.05)$ difference in the intestinal E. coli counts in group $\mathrm{T} 3$ and $\mathrm{T} 4$ compared to group $\mathrm{T} 1$ and $\mathrm{T} 2$, whereas no significant difference was observed between group T1 and $\mathrm{T} 2$ and also between group $\mathrm{T} 3$ and $\mathrm{T} 4$.

The intestinal Lactobacillus counts $\left(\log _{10}\right.$ $\mathrm{CFU} / \mathrm{g}$ ) in group $\mathrm{T} 1, \mathrm{~T} 2, \mathrm{~T} 3$ and $\mathrm{T} 4$ at $14^{\text {th }}$ day were $6.80 \pm 0.039,6.85 \pm 0.040,7.15 \pm 0.025$ and $7.17 \pm 0.030$, respectively. A significant $(\mathrm{P} \leq 0.05)$ difference was observed in the intestinal Lactobacillus counts among the treatments. The maximum Lactobacillus counts was observed in group T4 and T3 compared to T1 and T2. ANOVA revealed a significant $(\mathrm{P} \leq 0.05)$ difference in the intestinal Lactobacillus counts in group T3 and T4 compared to group $\mathrm{T} 1$ and $\mathrm{T} 2$, whereas no significant difference was observed between group $\mathrm{T} 1$ and $\mathrm{T} 2$ and also between group $\mathrm{T} 3$ and T4. At the end of $28^{\text {th }}$ day, the intestinal $E$. coli counts $\left(\log _{10} \mathrm{CFU} / \mathrm{g}\right)$ in group $\mathrm{T} 1, \mathrm{~T} 2, \mathrm{~T} 3$, T4, T5, T6 and T7 were 7.06 $\pm 0.030,7.02 \pm$ $0.023,6.71 \pm 0.029,6.74 \pm 0.039,6.92 \pm$ $0.028,6.65 \pm 0.045$ and $6.61 \pm 0.042$, respectively. A significant $(\mathrm{P} \leq 0.05)$ difference was observed in the intestinal $E$. coli counts among the treatments. The maximum $E$. coli counts were observed in group $\mathrm{T} 1$ and $\mathrm{T} 2$ compared to other treatment groups. ANOVA revealed a significant $(\mathrm{P} \leq 0.05)$ difference in the intestinal E. coli counts between group T1, T2 and T5 compared to group T7, T6, T3 and $\mathrm{T} 4$, whereas no significant difference was observed between group T1, T2 and T5 and also between group T7, T6, T3 and T4. The intestinal Lactobacillus counts $\left(\log _{10} \mathrm{CFU} / \mathrm{g}\right)$ in group $\mathrm{T} 1, \mathrm{~T} 2, \mathrm{~T} 3, \mathrm{~T} 4, \mathrm{~T} 5, \mathrm{~T} 6$ and $\mathrm{T} 7$ were $6.80 \pm 0.039,6.83 \pm 0.034,7.09 \pm 0.027,7.07$ $\pm 0.027,6.89 \pm 0.035,7.14 \pm 0.026$ and $7.16 \pm$ 0.022 , respectively. A significant $(\mathrm{P} \leq 0.05)$ difference was observed in the intestinal Lactobacillus counts among the treatments. The maximum Lactobacillus counts was observed in group T7, T6, T4 compared to other treatment groups. ANOVA revealed a significant $(\mathrm{P} \leq 0.05)$ difference in the intestinal Lactobacillus counts between group T1, T2 and T5 compared to group T7, T6, T3 and T4, whereas no significant difference was observed between group T1, T2 and T5 and also between group T7, T6, T3 and T4.

At the end of $42^{\text {nd }}$ day, the intestinal $E$. coli counts $\left(\log _{10} \mathrm{CFU} / \mathrm{g}\right)$ in group T1, T2, T3, T4, T5, T6, T7, T8, T9 and T10 were $7.09 \pm$ $0.042,7.07 \pm 0.011,6.88 \pm 0.030,6.88 \pm$ $0.030,6.91 \pm 0.029,6.46 \pm 0.055,6.41 \pm$ $0.055,6.71 \pm 0.022,6.54 \pm 0.047$ and $6.49 \pm$ 0.059 , respectively. A significant $(\mathrm{P} \leq 0.05)$ difference was observed in the intestinal $E$. coli counts among the treatments. The maximum E. coli counts was observed in group $\mathrm{T} 1$ and $\mathrm{T} 2$ compared to other treatment groups. ANOVA revealed a significant $(\mathrm{P} \leq 0.05)$ difference in the intestinal E. coli 
counts between group T1, T2 compared to groups $\mathrm{T} 3$ to $\mathrm{T} 10$, whereas no significant difference was observed between groups T3, T4, T5 and also between group T6, T7, T9 and T10. The intestinal Lactobacillus counts $\left(\log _{10}\right.$ CFU/g) in group T1, T2, T3, T4, T5, T6, T7, $\mathrm{T} 8, \mathrm{~T} 9$ and $\mathrm{T} 10$ were $6.68 \pm 0.049,6.69 \pm$ $0.048,7.00 \pm 0.037,7.05 \pm 0.021,6.80 \pm$ $0.044,7.17 \pm 0.025,7.18 \pm 0.016,6.90 \pm$ $0.035,7.20 \pm 0.013$ and $7.20 \pm 0.022$, respectively. A significant $(\mathrm{P} \leq 0.05)$ difference was observed in the intestinal Lactobacillus counts among the treatments. The maximum Lactobacillus counts was observed in group T10, T9, T7 and T6 compared to other treatment groups. ANOVA revealed a significant $(\mathrm{P} \leq 0.05)$ difference in the intestinal Lactobacillus counts between group T1, T2 compared to group $\mathrm{T} 3$ to $\mathrm{T} 10$, whereas no significant difference was observed between group T1 and T2 and also between group T6, T7, T9 and T10.

The result of feeding graded level of YEN up to 14 days in commercial broilers on intestinal E. coli counts $\left(\log _{10} \mathrm{CFU} / \mathrm{g}\right)$ revealed a significant $(\mathrm{P} \leq 0.05)$ decrease in counts in birds fed 2 and 3 per cent YEN as compared to control and 1 per cent YEN, whereas no significant $(\mathrm{P} \geq 0.05)$ difference in $\mathrm{E}$. coli counts was evident between control and 1 per cent YEN as well as between 2 and 3 per cent
YEN fed birds. The intestinal Lactobacillus counts $\left(\log _{10} \quad \mathrm{CFU} / \mathrm{g}\right)$ also revealed that inclusion of 2 and 3 per cent YEN resulted in a significant $(\mathrm{P} \leq 0.05) \quad$ increase in Lactobacillus counts as compared to control and 1 per cent YEN, whereas no significant $(\mathrm{P} \geq 0.05)$ difference could be observed between control and 1 per cent YEN as well as between 2 and 3 per cent YEN fed birds.

At the end of $28^{\text {th }}$ day, the intestinal E. coli counts $\left(\log _{10} \mathrm{CFU} / \mathrm{g}\right)$ revealed a significant $(\mathrm{P} \leq 0.05)$ decrease in the E. coli counts in birds fed 2 and 3 per cent YEN for 14 and 28 days. The maximum E. coli counts were observed in control and 1 per cent YEN fed birds up to 14 days. No significant $(\mathrm{P} \geq 0.05)$ difference in $\mathrm{E}$. coli count was observed between birds fed 2 and 3 per cent YEN fed up to 14 and 28 days as well as in birds fed 1 per cent Yen for 14 and 28 days. The intestinal Lactobacillus counts $\left(\log _{10} \quad \mathrm{CFU} / \mathrm{g}\right)$ was increased significantly $(\mathrm{P} \leq 0.05)$ with different levels of inclusion of YEN for 14 and 28 days. The maximum Lactobacillus counts was observed in group fed 2 and 3 per cent YEN for 28 days followed by 2 and 3 per cent YEN for 14 days. No significant $(\mathrm{P} \geq 0.05)$ difference among the birds fed 2 and 3 per cent YEN for 14 and 28 days as well as between control and 1 per cent YEN fed for 14 and 28 days.

Table.1 Description of the dietary treatment and period of feeding

\begin{tabular}{|c|c|c|}
\hline Treatment & Diet & Duration of treatment \\
\hline $\mathrm{T}_{1}$ & Control basal Diet & ---------- \\
\hline $\mathrm{T}_{2}$ & Control basal diet $+1 \%$ YEN & $1-14$ days \\
\hline $\mathrm{T}_{3}$ & Control basal diet $+2 \%$ YEN & $1-14$ days \\
\hline $\mathrm{T}_{4}$ & Control basal diet $+3 \%$ YEN & $1-14$ days \\
\hline $\mathrm{T}_{5}$ & Control basal diet $+1 \%$ YEN & $1-28$ days \\
\hline $\mathrm{T}_{6}$ & Control basal diet $+2 \%$ YEN & $1-28$ days \\
\hline $\mathrm{T}_{7}$ & Control basal diet $+3 \%$ YEN & $1-28$ days \\
\hline $\mathrm{T}_{8}$ & Control basal diet $+1 \%$ YEN & $1-42$ days \\
\hline $\mathrm{T}_{9}$ & Control basal diet $+2 \%$ YEN & $1-42$ days \\
\hline $\mathrm{T}_{10}$ & Control basal diet $+3 \%$ YEN & $1-42$ days \\
\hline
\end{tabular}


Table.2 Effect of feeding graded levels of yeast cell extracted nucleotides (YEN) on gut microbial load $\left(\log _{10} \mathrm{CFU} / \mathrm{g}\right)$ at the $14^{\text {th }}$ day in commercial broilers

\begin{tabular}{|c|c|c|}
\hline $\begin{array}{l}\text { Experimental } \\
\text { Group }\end{array}$ & $\begin{array}{c}E . \text { coli counts }\left(\log _{10}\right. \\
\text { CFU/g) }\end{array}$ & Lactobacillus count $\left(\log _{10} \mathrm{CFU} / \mathrm{g}\right)$ \\
\hline $\mathbf{T}_{1}$ & $7.14 \pm 0.025^{\mathrm{a}}$ & $6.80 \pm 0.039^{b}$ \\
\hline$T_{2}$ & $7.16 \pm 0.008^{a}$ & $6.85 \pm 0.040^{b}$ \\
\hline$T_{3}$ & $6.80 \pm 0.037^{b}$ & $7.15 \pm 0.025^{\mathrm{a}}$ \\
\hline $\mathrm{T}_{4}$ & $6.77 \pm 0.035^{b}$ & $7.17 \pm 0.030^{\mathrm{a}}$ \\
\hline
\end{tabular}

Table.3 Effect of feeding graded levels of yeast cell extracted nucleotides (YEN) on gut microbial load $\left(\log _{10} \mathrm{CFU} / \mathrm{g}\right)$ at the $28^{\text {th }}$ day in commercial broilers

\begin{tabular}{|c|c|c|}
\hline Experimental Group & $\boldsymbol{E}$. coli counts $\left(\log _{10} \mathbf{C F U} / \mathbf{g}\right)$ & Lactobacillus count $\left(\log _{10} \mathbf{C F U} / \mathbf{g}\right)$ \\
\hline $\mathbf{T}_{\mathbf{1}}$ & $7.06 \pm 0.030^{\mathrm{a}}$ & $6.80 \pm 0.039^{\mathrm{b}}$ \\
\hline $\mathbf{T}_{\mathbf{2}}$ & $7.02 \pm 0.023^{\mathrm{ab}}$ & $6.83 \pm 0.034^{\mathrm{b}}$ \\
\hline $\mathbf{T}_{\mathbf{3}}$ & $6.71 \pm 0.029^{\mathrm{cd}}$ & $7.09 \pm 0.027^{\mathrm{a}}$ \\
\hline $\mathbf{T}_{\mathbf{4}}$ & $6.74 \pm 0.039^{\mathrm{c}}$ & $7.07 \pm 0.027^{\mathrm{a}}$ \\
\hline $\mathbf{T}_{\mathbf{5}}$ & $6.92 \pm 0.028^{\mathrm{b}}$ & $6.89 \pm 0.035^{\mathrm{b}}$ \\
\hline $\mathbf{T}_{\mathbf{6}}$ & $6.65 \pm 0.045^{\mathrm{cd}}$ & $7.14 \pm 0.026^{\mathrm{a}}$ \\
\hline $\mathbf{T}_{\mathbf{7}}$ & $6.61 \pm 0.042^{\mathrm{d}}$ & $7.16 \pm 0.022^{\mathrm{a}}$ \\
\hline${ }_{\mathrm{a}, \mathrm{b}, \mathrm{c}, \mathrm{d}}{ }_{\text {Means in }}$ & & \\
\hline \multicolumn{2}{|c|}{}
\end{tabular}

Table.4 Effect of feeding graded levels of yeast cell extracted nucleotides (YEN) on gut microbial load $\left(\log _{10} \mathrm{CFU} / \mathrm{g}\right)$ at the $42^{\text {th }}$ day in commercial broilers

\begin{tabular}{|c|c|c|}
\hline Experimental Group & $\boldsymbol{E}$. coli counts $\left(\log _{10} \mathbf{C F U} / \mathbf{g}\right)$ & Lactobacillus count $\left(\log _{10} \mathbf{C F U} / \mathbf{g}\right)$ \\
\hline $\mathbf{T}_{\mathbf{1}}$ & $7.09 \pm 0.042^{\mathrm{a}}$ & $6.68 \pm 0.049^{\mathrm{e}}$ \\
\hline $\mathbf{T}_{\mathbf{2}}$ & $7.07 \pm 0.011^{\mathrm{a}}$ & $6.69 \pm 0.048^{\mathrm{e}}$ \\
\hline $\mathbf{T}_{\mathbf{3}}$ & $6.88 \pm 0.030^{\mathrm{b}}$ & $7.00 \pm 0.037^{\mathrm{bc}}$ \\
\hline $\mathbf{T}_{\mathbf{4}}$ & $6.88 \pm 0.030^{\mathrm{b}}$ & $7.05 \pm 0.021^{\mathrm{b}}$ \\
\hline $\mathbf{T}_{\mathbf{5}}$ & $6.91 \pm 0.029^{\mathrm{b}}$ & $6.80 \pm 0.044^{\mathrm{d}}$ \\
\hline $\mathbf{T}_{\mathbf{6}}$ & $6.46 \pm 0.055^{\mathrm{d}}$ & $7.17 \pm 0.025^{\mathrm{a}}$ \\
\hline $\mathbf{T}_{\mathbf{7}}$ & $6.41 \pm 0.055^{\mathrm{d}}$ & $7.18 \pm 0.016^{\mathrm{a}}$ \\
\hline $\mathbf{T}_{\mathbf{8}}$ & $6.71 \pm 0.022^{\mathrm{c}}$ & $6.90 \pm 0.035^{\mathrm{c}}$ \\
\hline $\mathbf{T}_{\mathbf{9}}$ & $6.54 \pm 0.047^{\mathrm{d}}$ & $7.20 \pm 0.013^{\mathrm{a}}$ \\
\hline $\mathbf{T}_{\mathbf{1 0}}$ & $6.49 \pm 0.059^{\mathrm{d}}$ & $7.20 \pm 0.022^{\mathrm{a}}$ \\
\hline a, b, c & & \\
\hline
\end{tabular}

At the end of $42^{\text {nd }}$ day, the intestinal E. coli counts $\left(\log _{10} \mathrm{CFU} / \mathrm{g}\right)$ revealed a significant $(\mathrm{P} \leq 0.05)$ decrease with inclusion of $\mathrm{YEN}$ and the lowest E. coli counts was observed in birds fed 2 and 3 per cent YEN up to 28 days followed by same levels of YEN at 42 days compared to other treatments. Feeding of YEN at 2 and 3 per cent up to 28 and 42 days did not reveal any significant $(\mathrm{P} \geq 0.05)$ difference in $\mathrm{E}$. coli counts and similarly no 
significant $(\mathrm{P} \geq 0.05)$ difference could be observed between birds fed 1, 2 and 3 per cent YEN up to 14 and 1 per cent YEN fed up to 28 and 42 days. The intestinal Lactobacillus counts $\left(\log _{10} \quad \mathrm{CFU} / \mathrm{g}\right)$ significantly $(\mathrm{P} \leq 0.05)$ increased in birds fed 2 and 3 per cent YEN up to 28 days followed by same levels of YEN at 42 days compared to other treatments. Feeding of YEN at 2 and 3 per cent up to 28 and 42 days did not reveal any significant $(\mathrm{P} \geq 0.05)$ difference in Lactobacillus counts and similarly no significant $(\mathrm{P} \geq 0.05)$ difference could be observed between birds fed 1, 2 and 3 per cent YEN up to 14 and 1 per cent YEN fed up to 28 and 42 days.

The results of the present study was in accordance with the findings of Olnood et al., (2015) who observed a significant decrease bacterial count in the caecal digesta with the number of Enterobacteria decreasing $(\mathrm{P} \leq$ 0.05) on day 7 and 21. Similarly, Senthilkumar et al., (2015) found that feeding of hydrolysed nucleotides and mannanglucans in broilers resulted in a significant improvement in Lactobacillus spp. Count. They also observed that inclusion of nucleotides resulted in a significant reduction in pathogenic gut microbes such as E. coli, Clostridium spp. and Salmonella spp. at end of $7^{\text {th }}$ and $14^{\text {th }}$ day of age.

Feeding of enzymatically hydrolysed whole Saccharomyces cerevisiae yeast (HY) and the pellets of yeast cell wall (YCW) in broiler up to 25 days of age resulted in increase in Lactobacillus in the duodenal and jejunal digesta as compared with the control (Muthusamy et al., 2011). Ghosh et al., (2011) compared the effects of an antibiotic growth promoter (AGP), yeast (Saccharomyces cerevisiae) and yeast cell wall (YCW) on microbiology of the small intestine in broiler chicks and observed that the mucosal Escherichia coli number was higher in the positive control group ( $\mathrm{p}<$ 0.001 ), whereas in the digesta $E$. coli number was lower in the positive control, Yeast and YCW groups in relation to the negative. Konca et al., (2009) evaluated the effects of dietary mannan oligosaccharide (MOS) and Saccharomyces cerevisiae (SC) in finishing turkeys' diets on intestinal microflora and opined that the ileum total bacteria, gram negative bacteria and $E$. coli counts in the SC group were lower than those of the control and MOS groups $(\mathrm{P}<0.05)$.

Sirviydis et al., (2006) reported that cell wall's components of yeasts (Saccharomyces cerevisiae) provide alternate binding sites for pathogenic bacteria and there by reduces the level of pathogenic bacteria in gut. Muthusamy et al., (2011) reported that Yeast derived products are positively associate with gut wall and favour an increase in number of natural Lactobacillus which in turn suppress the growth of undesirable enteric microorganisms such as E. coli which is evident in the present study.

Based on the results on the effect of YEN on gut microflora, it was evident that feeding of YEN at 2 and 3 per cent in birds from 14 days till 42 days resulted in significant $(\mathrm{P} \leq 0.05)$ decrease in pathogenic E. coli and increase in beneficial Lactobacillus. However, feeding YEN at 2 and 3 per cent up to 28 days was superior compared to 14 days and no difference could be observed between 28 and 42 days feeding of YEN. Hence, it is advocated that feeding YEN at 2 or 3 per cent up to 28 days would have better effect on gut microflora.

\section{References}

Brümmer, M., C. Jansen Van Rensburg and C. Moran., 2010. Saccharomyces cerevisiae cell wall products: the effects on gut morphology and performance of 
broiler chickens. South African J. of Anim. Sci., 40: 14-21.

Cogliani, C., H. Goossens and C. Greko., 2010. Restricting antimicrobial use in food animals: lessons from Europe. Microbe, 6: 274.

Ghosh, T., Haldar, S., Bedford, M., Muthusami, N. and Samanta, I., 2011. Assessment of yeast cell wall as replacements for antibiotic growth promoters in broiler diets: Effects on performance, intestinal histomorphology and humoral immune responses. J. Anim. Physiol Anim. Nutr., 96: 275-84.

Li, P., G. S. Burr., J. Goff., K. W. Whiteman., K. B. Davis., R. R. Vega., W. H. Neill and D. M. Gatlin., 2005. A preliminary study on the effects of dietary supplementation of brewer's yeast and nucleotides, singularly or in combination, on juvenile red drum (Sciaenops ocellatus). Aquacult. Res., 36: 1120-1127.

Mackie and Mc Cartey., 1996. Practical medical microbiology. Churchill Livingstone New York.

Mateo, C. and H. Stein., 2004. Nucleotides and young animal health: can we enhance intestinal tract development and immune function. Proc. Annual symposium on nutritional bio technology in the feed and food industries, pp 159-168.
Muthusamy, N., Haldar, S., Ghosh, T. K. and Bedford, M. R., 2011. Effects of hydrolysed Saccharomyces cerevisiae yeast and yeast cell wall components on live performance, intestinal histomorphology and humoral immune response of broilers. Brit. Poult Sci., 54(6): 694-703.

Olnood, C.G., Sleman, S.M., Beski, Paul., A. Iji and Mingan Choct., 2015. Delivery routes for probiotics: Effects on broiler performance, intestinal morphology and gut microflora. Anim. Nutr., 1: 192-202.

Postgate J. R., 1969. Viable counts and viability. In: Methods in microbiology. Vol. I Norris, Jr and Robbins, D. W., Eds Academic press, pp $611-628$.

Senthilkumar, S., P. Vasanthkumar, M.R. Purushotham and D. Chandrasekaran, 2015. Gut ecology of broilers fed enzymes complex with hydrolysed nucleotides and mannanglucans supplemented diets. Int.J.Inno.Res.in Tech.Sci.Eng., 1(4): 125-128.

Sirviydis, V., Bobiniene, R., Gudaviciute, D., Cepuliene, R., Semska, V., Vencius, D. and Kepaliene, I., 2006. Influence of a prebiotic feed additive on some biochemical indices of blood and intestinal microbiota of broiler chicken. Zemes Ukio Mokoslai., 4: 57-62.

Weir, D.M., 1990. Hand book of experimental immunology. I: 2nd Edn.

\section{How to cite this article:}

Indresh, H.C., Jayanaik, H.D. Narayanaswamy, M.C. Shivakumar, T. Munegowda and Umashankar, B.C. 2018. Effect of Feeding Graded Dietary Levels of Yeast Cell Extracted Nucleotides (YEN) at Different Age Intervals on Gut (Intestinal) Microbial Load of Commercial Broilers. Int.J.Curr.Microbiol.App.Sci. 7(05): 1530-1536. doi: $\underline{\text { https://doi.org/10.20546/ijcmas.2018.705.180 }}$ 